\title{
PERLINDUNGAN KONSUMEN BAGI PASIEN PENGGUNA KARTU BPJS DI RSUD ARIFIN ACHMAD PROVINSI RIAU
}

\author{
Irfan Ridha \\ Program Pascasarjana Fakultas Hukum Universitas Riau \\ Email: irfanridha74@gmail.com
}

\begin{abstract}
BPJS a poverty reduction which aims to have access and quality of health care of the poor can be improved so that no poor people who have difficulty accesin health care service by reason of lack of funds. Formation BPJS in Law No. 24 on BPJS. The research problem is whether the patient card users BPJS at Arifin Achmad Hospital Riau Province to obtain protection of consumers and how to shape consumer protection against card users BPJS patients at Arifin Achmad Riau province by Law No. 8 of 1999 on consumer protection in 2015. This study examines the empirical juridical legal aspects nmelihat implementation in the field. This research was conducted by Observational Research, is to survey. Data collectors in the form of questionnaires and interviews, while the nature of the research is descriptive of providing an overview of the issues examined. Respondents were patients BPJS card users and the hospitals Pekanbaru. The conclusion of this study is to unsatisfactory services provided by the City Hospital Pekanbaru to patients BPJS card users due to lack of patient understanding about their rights and obligations. So they were not able to do anything in case of misuse of their rights. Majanemen Hospital who are not professional is also an inhibiting factor in the provision of services that are good for society.
\end{abstract}

\section{Kata Kunci: BPJS, Kesehatan, Konsumen}

\section{A. Latar Belakang}

Ciri utama walfare state adalah munculnya kewajiban pemerintah untuk mewujudkan kesejahteraan umum bagi warga warganya. Dengan kata lain ajaran walfare state merupakan bentuk peralihan prinsip staatsonthouding (pembatasan peran Negara dan pemerintah untuk mencampuri kehidupan ekonomi dan sosial masyarakat) menjadi staatsbemoeienis yang menghendaki negara dan pemerintah terlibat aktif dalam kehidupan ekonomi dan sosial, sebagai langkah untuk mewujudkan kesejahteraan umum, selain menjalankan ketertiban dan keamanan/ rust en orde (Ridwan HR, 2006: 15). 
Adanya BPJS (Badan Penyelenggara Jaminan Sosial), itu sebenarnya sudah menuju arah yang lebih baik, sehingga harus dibuat sebagai kebijakan yang sustainable atau berlanjut. BOK (Bantuan Operasional Kesehatan) atau bantuan untuk daerah tertinggal itu kebijakan setengah hati. Indonesia tidak mau membuat platform kebijakan yang mapan terutama BPJS karena menyangkut kesehatan masyarakat.

Peraturan perundang-undangan yang menjadi landasan penyelenggaraan pelayanan kesehatan bagi masyarakat. Adapun yang diatur dalam Undang-undang dan peraturan pemerintah lain. Dalam UUD 1945 (Amandemen) pada pasal $28 \mathrm{H}$ angka (1): "setiap orang berhak hidup sejahtera lahir dan batin, bertempat tinggal dan mendapatkan lingkungan hidup yang baik dan sehat serta berhak memperoleh pelayanan kesehatan".

Pada Pasal 34 angka (3): "Negara bertanggungjawab atas pengadaan fasilitas pelayanan kesehatan dan fasilitas pelayanan umum yang layak." Undangundang Nomor 23 Tahun 1992 tentang kesehatan juga mengatur yang tertera pada Pasal 4: "setiap orang mempunyai hak yang sama dalam memperoleh derajat kesehatan yang optimal".

Sehingga tidak ada istilah diskriminasi dalam pemberian pelayanan kesehatan oleh pihak Rumah Sakit. Pada pasal 5 dinyatakan: "setiap orang berkewajiban untuk ikut serta dalam memelihara dan meningkatkan derajat kesehatan personalnya, keluarga dan lingkungannya." Pada Pasal 65 dinyatakan bahwa: "penyelenggaraan upaya kesehatan dibiayai pemerintah dan atau masyarakat.“

Pemberian layanan kesehatan menyangkut hubungan antara tenaga kesehatan dan konsumen (penerima layanan kesehatan) pemerintah telah mengatur perlindungan hukum terhadap kedua belah pihak (Yusuf Shofie 2003: 113). Sebagai konsumen pasien pengguna kartu BPJS memiliki hak yang sama dengan pasien lain, yang maksudnya sesama konsumen. Dalam Undang-undang Nomor 8 Tahun 1999 disebutkan bahwa "perlindungan konsumen berasaskan manfaat, keadilan, keseimbangan dan keselamatan serta kepastian hukum”. 
Banyak kasus pelanggaran terhadap hak konsumen sebagai pasien pengguna BPJS. Di tahun 2015 banyak temuan kasus peserta BPJS Kesehatan yang dijerumuskan dengan dalih ruang rawat penuh, peralatan kurang dan lainnya. Karena itu, pihaknya terus mengintensifkan penggalian fakta dan bukti-bukti jika ditemukan maka yang bersangkutan bisa dikenakan sanksi hukum baik peorangan dan juga manejemen RS.

Pada Pasal 73 Undang-Undang Nomor 23 Tahun 1992 tentang kesehatan berbunyi: "Pemerintah melakukan pembinaan terhadap semua kegiatan yang berkaitan dengan penyelenggaraan upaya kesehatan".

Pogram BPJS sekarang ini sudah mulai banyak pesertanya yang hingga Mei 2015 berjumlah 143 juta jiwa. Hingga akhir 2014, jumlah peserta BPJS Kesehatan sebanyak 133,4 juta jiwa. Kemudian, jumlah peserta bertambah menjadi 143 juta hingga pertengahan Mei 2015. Ada sekitar 10 juta peserta baru,dengan 1.739 RS Swasta dan RS pemerintah sebagai pemberi Fasilitas kesehatan (FASKES) di seluruh Indonesia (Riau Pos 2015: 22).

Peserta BPJS Kesehatan adalah setiap orang, termasuk orang asing yang kerja paling singkat 6 (enam) bulan di Indonesia, yang telah membayar iuran. Program pemerintah membantu masyarakat mendapatkan pelayanan kesehatan secara maksimal belum berjalan seperti yang diharapkan. Masih ditemukan pelayanan yang tidak layak diberikan kepada pasien pemilik kartu BPJS jika dibandingkan dengan pasien lainnya. Pelayanan yang diberikan sangat lamban dan tidak jarang mereka bahkan menelantarkan pasien yang menggunakan kartu BPJS.

Keterlambatan penanganan yang dilakukan oleh tenaga medis bisa membuat penyakit yang diderita pesien pengguna kartu BPJS akan menjadi lebih parah atau bahkan bisa menghilangkan nyawa seseorang. Apakah tindakan demikian bisa diterima oleh masyarakat miskin. Seakan nyawa itu tiada arti lagi bagi mereka sebagai tenaga medis.

Berdasarkan pengamatan awal penulis dilapangan di RSUD Provinsi Riau, diperoleh keluhan-keluhan pasien pengguna kartu BPJS sebagai berikut: 
1. Pemberian kartu miskin pada orang yang tidak tepat. Dalam hal ini pendataan yang tidak falid, yaitu ada masyarakat yang mampu diberi kartu miskin sedangkan ditempat yang sama masyarakat miskin ditempat tersebut ada yang tidak mendapatkan kartu miskin.

2. Adanya pungutan biaya yang dilakukan oleh pihak Rumah Sakit terhadap pasien pengguna kartu miskin dengan alasan penyakit yang diderita oleh pasien tidak termasuk dalam daftar tanggungan BPJS. Padahal pemerintah telah menyatakan pengobatan gratis bagi masyarakat yang mendapat kartu BPJS.

3. Pelayanan yang diberikan terhadap pasien pengguna kartu BPJS dari segi pananganan pasien lamban, jika dibandingkan dengan pasien umum. Benar mereka tidak membayar tetapi semua biaya yang akan dikeluarkan oleh Rumah Sakit sudah menjadi tanggungan pemerintah tindakan ini melanggar pasal 4 Undang-Undang No. 8 tahun 1999 tentang perlindungan konsumen yang disebutkan bahwa setiap konsumen berhak untuk diperlakukan atau dilayani secara benar dan jujur serta tidak diskriminatif.

Menurut data BPJS, hingga Januari 2015 terdapat 135,7 juta peserta. Mereka terdiri atas 86,4 juta peserta penerima bantuan iuran, 8,89 juta peserta dari Jamkesda, 11 juta peserta dari golongan pekerja penerima upah (yang iurannya dibayar oleh pemberi kerja dan pekerja), serta 9,8 juta dari peserta mandiri atau penerima upah bukan pekerja yang membayarkan iuran sendiri. Sisanya, 19,61 juta dari PNS, TNI, Polri, dan bukan pekerja. Jumlah peserta Badan Penyelenggara Jaminan Sosial (BPJS) Kesehatan cabang Pekanbaru, saat ini lebih dari 1,4 juta peserta (http//www.bpjs.com).

Bertitik tolak dari uraian tersebut diatas, maka penulis mempunyai ketertarikan tersendiri melakukan penelitian mengenai perlindungan konsumen pengguna kartu miskin kemudian menuangkan kedalam suatu karya ilmiah yang berbentuk Tesis dengan judul: "Perlindungan Konsumen Terhadap Pasien Pengguna Kartu BPJS (Badan Penyelenggara Jaminan Sosial) di RSUD (Rumah Sakit Umum Daerah) Arifin Achmad Provinsi Riau Ditinjau Berdasarkan Undang-Undang Nomor 8 Tahun 1999 Tentang Perlindungan Konsumen.” 


\section{B. Metode Penelitian}

Jenis penelitian hukum dapat dibedakan menjadi penelitian hukum normatif dan penelitian hukum empiris/sosiologis. Penelitian hukum normatif merupakan penelitian yang datanya bersumber pada data sekunder dan berhubung data penelitian ini adalah data sekunder, maka termasuk dalam jenis penelitian hukum normatif. Sifat penelitian ini adalah deskriptif, yang bertujuan untuk memberikan gambaran tentang gejala-gejala sosial yang terkait dengan masalah Perlindungan Konsumen Terhadap Pasien Pengguna Kartu BPJS (Badan Penyelenggara Jaminan Sosial). Sumber data penelitian berupa bahan hukum primer, bahan hukum sekunder dan bahan hukum tersier. Metode pengumpulan data dilakukan menggunakan teknik studi dokumen, yang dianalisis dengan menggunakan teknik analisis kualitatif.

\section{Hasil Penelitian dan Analisis}

\section{Perlindungan konsumen terhadap pasien pengguna kartu BPJS}

\section{a. Standar pelayanan medis}

Pelayanan kesehatan (medis) merupakan hal yang penting yang harus dijaga maupun ditingkatkan kualitasnya sesuai standar pelayanan yang berlaku, agar masyarakat sebagai konsumen dapat merasakan pelayanan yang diberikan. Dalam penelitian ini, rumah sakit yang diteliti oleh peneliti adalah RSUD Arifin Ahmad Provinsi Riau. Pada rumah sakit ini, tercatat data pengguna kartu BPJS. Total penerimaan Jaminan Kesehatan Riau Tahun 2015 adalah 1,4 juta orang, jumlah ini didistribusikan oleh kabupaten/kota sesuai dengan pengajuan daerah untuk masyarakat. Dalam kuota yang ditetapkan pusat untuk BPJS, Riau akan dikucurkan anggaran sebesar Rp 16 Miliar.

Kartu BPJS dapat diperoleh setiap masyarakat ekonomi lemah dengan mengikuti prosedur yang ada. Adapun prosedur pembuatan kartu BPJS, antara lain:

1) Masyarakat yang membutuhkan pelayanan kesehatan kartu BPJS harus memenenuhi syarat yang telah ditentukan yaitu adanya surat keterangan tidak mampu (SKTM) dari RT, RW setempat dan kepada Lurah. 
2) Dengan adanya kartu miskin ini, masyarakat selanjutnya menyerahkan kartu miskin dan lampiran yang dibutuhkan untuk mengurus kartu BPJS kepada BPJS

3) BPJS terlebih dahulu memproses apakah masyarakat ini berhak dan merupakan kategori keluarga miskin.

Apabila masyarakat ini dinyatakan layak untuk mendapatkan kartu BPJS dengan premi paling rendah, maka pihak BPJS akan segera mengeluarkan kartu BPJS yang dapat dipergunakan oleh masyarakat dalam proses pemeliharaan kesehatannya. Dalam pembuatan kartu BPJS, dapat saja terjadi hambatanhambatan, baik karena prosedur yang sulit ataupun karena masyarakat sebagai konsumen yang tidak memahami prosedur pembuatan kartu BPJS tersebut, tetapi berdasarkan hasil penelitian, dapat diketahui bahwa pembuatan kartu BPJS ini sering terhambat karena prosedurnya yang sulit, seperti terlihat pada tabel berikut:

Tabel 1

Jawaban Responden Mengenai Prosedur Pembuatan Kartu BPJS

\begin{tabular}{llcc}
\hline No. & Jawaban Responden & Jumlah & Persentase \\
\hline 1. & Mudah & 12 & $19,67 \%$ \\
2. & Dipersulit & 53 & $80,32 \%$ \\
\hline \multicolumn{2}{r}{ Jumlah } & 65 & $100,00 \%$ \\
\hline
\end{tabular}

Sumber: Data lapangan diolah tahun 2016

Berdasarkan tabel diatas, dapat dilihat bahwa jumlah masyarakat yang mendapatkan proses prosedur untuk mendapatkan kartu BPJS dengan mudah tanpa berbelit-belit hanya sebanyak 12 orang atau 19,67 \% dari reponden. Sedangkan proses yang berbelit-belit ditunjukan dengan jumlah yang besar yaitu sebanyak 53 orang atau 80,32 \% dari responden. Dengan jumlah persentase ini, menunjukan bahwa pelayanan kepada masyarakat mengenai pembuatan kartu ini masih jauh dari apa yang diharapkan.

Pelayanan kesehatan diatas, merupakan salah satu hak yang dapat diperoleh bagi pengguna kartu BPJS. Hal ini dapat dilihat pada tabel berikut: 
Tabel 2

Jawaban Responden yang Mengetahui ketentuan Pelayanan Kesehatan bagi Pengguna Kartu BPJS

\begin{tabular}{cccc}
\hline No. Jawaban Responden & Jumlah & Persentase \\
\hline 1. Mengetahui seluruhnya & 7 & $9,84 \%$ \\
2. Mengetahui sebagian & 18 & $21,31 \%$ \\
3. Tidak mengetahui sama sekali & 40 & $68,85 \%$ \\
\hline & Jumlah & 65 & $100,00 \%$ \\
\hline
\end{tabular}

Sumber: Data Lapangan diolah Tahun 2016

Berdasarkan Tabel 3.2 di atas dapat dilihat, pasien yang mengetahui secara keseluruhan tentang ketentuan-ketentuan pelaksanaan pelayanan kesehatan BPJS berjumlah 7 orang atau $9.84 \%$ dari jumlah responden, pasien mengetahui sebagian pelaksanaan pelayanan kesehatan BPJS sebanyak 18 orang atau 21,31\% dari responden, sementara jumlah terbanyak yang tidak mengetahui sama sekali tentang pelayanan kesehatan BPJS adalah sebanyak 40 orang atau sebesar $68,85 \%$ dari responden. Dari gambaran diatas dapat disimpulkan bahwa pasien pengguna kartu BPJS tidak mengetahui tentang ketentuan yang mengatur pelayanan kesehatan bagi pengguna kartu BPJS dengan premi paling rendah.

Banyak pengguna kartu BPJS yang tidak mengetahui apa yang menjadi haknya sebagai pengguna kartu BPJS.

Tabel 3

Jawaban Responden yang Mengetahui Hak-Hak Pasien Pengguna Kartu BPJS

\begin{tabular}{|c|c|c|c|}
\hline No. & Jawaban Responden & Jumlah & Persentase \\
\hline 1. & Mengetahui seluruhnya & 4 & $0,00 \%$ \\
\hline 2. & Mengetahui sebagian & 12 & $19,67 \%$ \\
\hline \multirow[t]{2}{*}{3.} & Tidak mengetahui sama sekali & 49 & $80,33 \%$ \\
\hline & Jumlah & 65 & $100,00 \%$ \\
\hline
\end{tabular}

Sumber: Data lapangan diolah 2016 
Berdasarkan tabel diatas dapat diketahui bahwa pasien pengguna kartu BPJS hanya 4 orang yang mengetahui secara keseluruhan mengenai haknya atas kartu BPJS tersebut. Kebanyakan pasien tidak mengetahui haknya atas kartu BPJS yaitu sebanyak 49 orang atau 80,33 \% dari jumlah responden. Pasien yang mengetahui sebagian hak atas kartu BPJS hanya berjumlah 12 orang atau 19,67\% dari jumlah responden. Kebanyakan pasien pengguna kartu BPJS tidak mengetahui apa yang menjadi haknya atas kartu BPJS.

Ketidaktahuan pasien mengenai haknya sebagai pengguna BPJS, juga diikuti ketidaktahuan pasien akan jenis pelayanan yang ada di RSUD Kota Pekanbaru. sebagaimana dilihat dalam tabel di bawah ini :

\section{Tabel 4}

Jawaban Responden yang Mengetahui Jenis Pelayanan Kesehatan Pihak Rumah Sakit (RSUD Kota Pekanbaru) kepada Pasien Pengguna Kartu BPJS

\begin{tabular}{clcc}
\hline No. Jawaban Responden & Jumlah & Persentase \\
\hline 1. Mengetahui seluruhnya & 0 & $0,00 \%$ \\
2. Mengetahui sebagian & 48 & $78,68 \%$ \\
3. Tidak mengetahui sama sekali & 13 & $21,32 \%$ \\
\hline & 61 & $100,00 \%$ \\
\hline
\end{tabular}

Sumber: Data lapangan diolah 2016

Dari tabel diatas, dapat diketahui bahwa tidak ada satupun pasien yang mengetahui seluruhnya mengenai jenis pelayanan kesehatan yang ada dirumah sakit. Sebanyak 48 orang atau sebesar 78,68 \% dari jumlah responden yang mengetahui sebagian saja jenis pelayanan di RSUD Arifin Ahmad. Sedangkan yang lainnya sebanyak 13 orang atau sebesar 21,32 \% dari responden tidak mengetahui sama sekali.

Selain keluhan atas jenis pelayanan RSUD Arifin Ahmad yang kurang diketahui pasien pengguna kartu BPJS, ternyata pasien pengguna kartu BPJS juga memberikan keluhan akan keterbatasan obat-obatan yang dimiliki RSUD Arifin Ahmad. Dapat disimpulkan bahwa obat-obatan yang diberikan oleh pihak RSUD 
Kota Pekanbaru masih kurang mencukupi kebutuhan pasien pengguna kartu BPJS dapat dilihat pada tabel di bawah ini:

Tabel 5

Jawaban Responden Mengenai Penyebab Obat-obatan yang Tidak Mencukupi

\begin{tabular}{clcc}
\hline No. Jawaban Responden & Jumlah & Persentase \\
\hline 1. Persediaan obat yang dibutuhkan terbatas. & 7 & $4,92 \%$ \\
2. Jenis obat yang dibutuhkan oleh pasien & 58 & $95,08 \%$ \\
& $\begin{array}{l}\text { Pengguna kartu miskin tidak ditanggung } \\
\text { oleh BPJS. }\end{array}$ & 65 & $100,00 \%$ \\
\hline
\end{tabular}

Sumber: Data lapangan diolah 2016

Dilihat dari tabel diatas, dapat diketahui bahwa yang menyatakan persediaan obat yang dibutuhkan terbatas hanya 7 orang atau sebesar 4,92\% dari jumlah responden sedangkan alasan jenis obat yang dibutuhkan tidak ditanggung oleh PT. BPJS adalah sebanyak 58 orang atau sebesar 95,08 \% dari responden. Dari tabel diatas dapat disimpulkan bahwa obat-obat tidak mencukupi karena jenis obat yang dibutuhkan tidak ditanggung oleh BPJS.

Pelayanan kesehatan yang diberikan pihak RSUD Arifin Ahmad kepada pasien pengguna kartu BPJS secara keseluruhan belum dapat memuaskan.Dilihat pada tabel berikut ini:

Tabel 6

Jawaban Responden Mengenai Pelayanan Kesehatan yang Diberikan Pihak RSUD Kota Pekanbaru

\begin{tabular}{cccc}
\hline No. Jawaban Responden & Jumlah & Persentase \\
\hline 1. Sudah memuaskan & 0 & $0,00 \%$ \\
2. Kurang memuaskan & 54 & $88,53 \%$ \\
3. Belum memuaskan & 7 & $11,47 \%$ \\
\hline & Jumlah & 61 & $100,00 \%$ \\
\hline
\end{tabular}

Sumber: Data lapangan diolah tahun 2016 
Dari tabel diatas dapat diketahui bahwa pasien pengguna kartu BPJS yang menyatakan belum memuaskan hanya 7 orang atau sebesar 11,47 \% dari responden, sisanya menyatakan bahwa pelayanan yang diberikan kurang memuaskan sebanyak 54 orang atau 88,53\% dari responden dan tidak ada satu orang pun yang menyatakan sudah memuaskan. Dari gambaran diatas dapat disimpulkan bahwa pelayanan yang diberikan pihak RSUD Kota Pekanbaru masih harus ditingkatkan lagi.

Selama ini banyak temuan kasus peserta BPJS Kesehatan yang dijerumuskan dengan dalih ruang rawat penuh, peralatan kurang dan lainnya. Karena itu, pihaknya terus mengintensifkan penggalian fakta dan bukti-bukti jika ditemukan maka yang bersangkutan bisa dikenakan sanksi hukum baik peorangan dan manejemen RS. Tidak hanya Rumah Sakit pemerintah, Rumah Sakit swasta pun melakukan kesalahan mengenai pelayanan terhadap pasien BPJS.

\section{b. Faktor penghambat pelayanan kesehatan kepada pasien BPJS}

Hambatan-hambatan dalam pelaksanaan pemberian pelayanan kesehatan di RSUD kota Pekanbaru bagi pasien pengguna kartu BPJS, berdasarkan wawancara dengan pihak RSUD Kota Pekanbaru menjelaskan bahwa pada umumnya masyarakat pengguna kartu BPJS tidak mengetahui atau kurang mengerti tentang tata cara pelaksanaan dari kartu BPJS sehingga sering terjadi hambatan-hambatan dalam pemberian jaminan pelayanan kesehatan tersebut, sedangkan paramedis kurang dalam memberikan penyuluhan atau pemberitahuan informasi tentang tata cara pelaksanaan pemberian pelayanan kesehatan kepada para pasien pengguna kartu BPJS.

Adapun faktor-faktor penghambat dalam pemberian perlindungan konsumen pada pasien pengguna kartu BPJS premi paling rendah, yaitu:

1) Kurangnya fasilitas atau sarana prasarana yang tersedia di RSUD Arifin Achmad Kota Pekanbaru. Berdasarkan hasil pengamatan peneliti, bagi pengguna kartu BPJS sarana dan prasarana yang digunakan masih jauh dari kelayakan seperti ruangan inap pasien masih jauh dari apa yang diterima masyarakat umum lainnya. Selain ruang inap, ketersediaan obat-obatan juga masih minim. 
2) Lambatnya pemerintah dalam penyaluran dana ke Rumah Sakit sehingga pihak Rumah Sakit sulit untuk menjalankan operasionalnya. Banyakya birokrasi pencairan dana serta lambatnya penyaluran dana dari pemerintah.

3) Kurangnya pengetahuan pasien mengenai kartu BPJS. Masyarakat banyak yang kurang mengetahui manfaat dan fungsi dari kartu BPJS tersebut, terutama masyarakat miskin. Padahal kartu BPJS ini merupakan bentuk upaya pemerintah dalam menjamin kesehatan masyarakat miskin.

4) Kurangnya sosialisasi tentang manfaat dan kegunaan kartu BPJS yang dilakukan oleh pihak BPJS terhadap masyarakat pengguna kartu BPJS. Dari hasil penelitian yang dilakukan pada RSUD Arifin Ahmad dapat disimpulkan bahwa kebutuhan akan pelayanan di RSUD Arifin Achmad Kota Pekanbaru semakin meningkat dikarenakan semakin besarnya angka pertumbuhan penduduk.

5) Prosedur pembuatan SKTM (Surat Keterangan Tidak Mampu) dan Kartu BPJS yang berbelit-belit serta memakan waktu lama. Manajemen pihak RSUD Arifin Achmad Kota Pekanbaru yang tidak profesional.

\section{Perlindungan konsumen terhadap pasien pengguna kartu BPJS}

Berdasarkan dimensi kualitas layanan kesehatan maka harapan pasien sebagai konsumen medis meliputi:

a. Pemberian pelayanan yang dijanjikan dengan segera dan memuaskan.

b. Membantu dan memberikan pelayanan dengan tanggap tanpa membedakan pelayanan dengan tanggap tanpa membedakan unsur SARA (suku, agama, ras, dan antar golongan).

c. Jaminan keamanan, keselamatan dan kenyamanan.

d. Komunikasi yang baik dan memahami kebutuhan pasien.

Selain harapan tersebut, terdapat beberapa hak yang dimiliki oleh seorang pasien yang harus dilakukan oleh dokter. Ada konsekuensi bagi seorang dokter dalam menjalankan profesinya untuk merealisasikan hak- hak yang dimiliki oleh seorang pasien, dengan mengkomunikasikan setiap tindakan terapeutik itu kepada pasiennya. 
Apabila dirumuskan, maka hak pasien sebagai konsumen pelayanan medis yang ditentukan dalam Undang-undang Nomor 23 Tahun 1992 tentang Kesehatan, antara lain:

a. Memperoleh informasi yang benar dan lengkap tentang keadaan dirinya;

b. Memberikan persetujuan ataupun penolakan terhadap terapi yang dilakukan atas dirinya;

c. Menjaga rahasia kedokteran terkait dengan kondisi dan layanan medis lainnya;

d. Opini kedua (second opinion).

Ikatan Dokter Indonesia (IDI) pada akhir Oktober tahun 2000 juga telah berikrar tentang hak dan kewajiban pasien dan dokter, yang wajib diketahui dan dipatuhi oleh seluruh dokter di Indonesia. Salah satu hak pasien yang utama dalam ikrar tersebut adalah hak untuk menentukan nasibnya sendiri, yang merupakan bagian dari hak asasi manusia, serta hak atas rahasia kedokteran terhadap riwayat penyakit yang dideritanya.

Hak menentukan nasibnya sendiri berarti memilih dokter, perawat dan sarana kesehatannya yang baik serta hak untuk menerima, menolak atau menghentikan pengobatan atau perawatan atas dirinya, tentu saja setelah menerima informasi yang lengkap mengenai keadaan kesehatan atau penyakitnya (Illowirawan http;//ilowirawan.wordpress.com/about/hak dan kewajiban Pasien).

Di Indonesia ketentuan tentang informed consent ini diatur melalui Peraturan Pemerintah Nomor 18 Tahun 1981 dan Surat Keputusan Pengurus Besar Ikatan Dokter Indonesia (IDI) Nomor 319/PB/A4/88.

\section{Upaya pasien pengguna kartu BPJS yang mendapatkan pelayanan tidak} layak

Jika produsen telah melanggar hak-hak konsumen, dalam hal ini pasien pengguna kartu miskin sebagai konsumen yang haknya dilindungi yang telah dijelaskan dalam UU No. 8 Tahun 1999 tentang perlindungan konsumen. Konsumen dalam hal ini pasien dapat menggunakan upaya hukum untuk melindungi hak-hak mereka yang telah dilanggar.

Ada upaya hukum yang dapat dilakukan yang telah diatur pada Pasal 45 UU Perlindungan Konsumen, yakni: 
Ayat (1): Setiap konsumen yang dirugikan dapat menggugat pelaku usaha melalui lembaga yang bertugas menyelesaikan sengketa antar konsumen dan pelaku usaha atau melalui peradilan yang berada dilingkungan peradilan umum.

Ayat (2): Penyelesaian sengketa konsumen dapat ditempuh melalui pengadilan atau di luar pengadilan berdasarkan pilhan sukarela para peserta yang bersengketa.

Ayat (3): Penyelesaian sengketa di luar pengadilan sebagimana dimaksud pada ayat (2) tidak menghilangkan tanggung jawab pidana sebagaimana diatur dalam undang-undang.

Ayat (4): Apabila telah dipilih upaya penyelesaian sengketa konsumen luar pengadilan gugatan melalui pengadilan hanya ditempuh apabila upaya tersebut dinyatakan tidak adil oleh salah satu pihak atau para pihak yang bersengketa.

Pada Tahun 2015 pengaduan pasien pemegang kartu BPJS yang masuk ke bagian pengaduan masyarakat RSUD Arifin Ahmad, sebagai berikut:

a. Pengaduan medis

Pengaduan medis ini terdiri dari 565 kasus pada tahun 2015. Pengaduan medis ini terdiri dari keluhan pasien pemegang kartu BPJS mengenai:

1) Batalnya operasi dikarenakan tidak adanya peralatan operasi.

2) Operasi batal dikarenakan tidak adanya obat.

3) Tidak tersedianya obat yang dibutuhkan oleh pasien.

4) Pasien tidak divisit oleh dokter.

5) Adanya ketidakpuasan pasien terhadap pelayanan pihak RSUD Arifin Ahmad.

b. Pengaduan mengenai administrasi

Pengaduan mengenai administrasi RSUD yang terjadi pada tahun 2015 adalah sebanyak 55 kasus.

1) Adanya penolakan petugas RSUD Arifin Ahmad terhadap pasien yang mengajukan pengobatan dengan menggunakan kartu BPJS.

2) Adanya perubahan status pasien dari pasien umum menjadi BPJS.

3) Perpindahan kelas rawat inap dari kelas yang rendah kelebih tinggi. 


\section{Tabel 7}

\section{Pengaduan Pasien RSUD Arifin Achmad Pekanbaru}

Tahun 2015

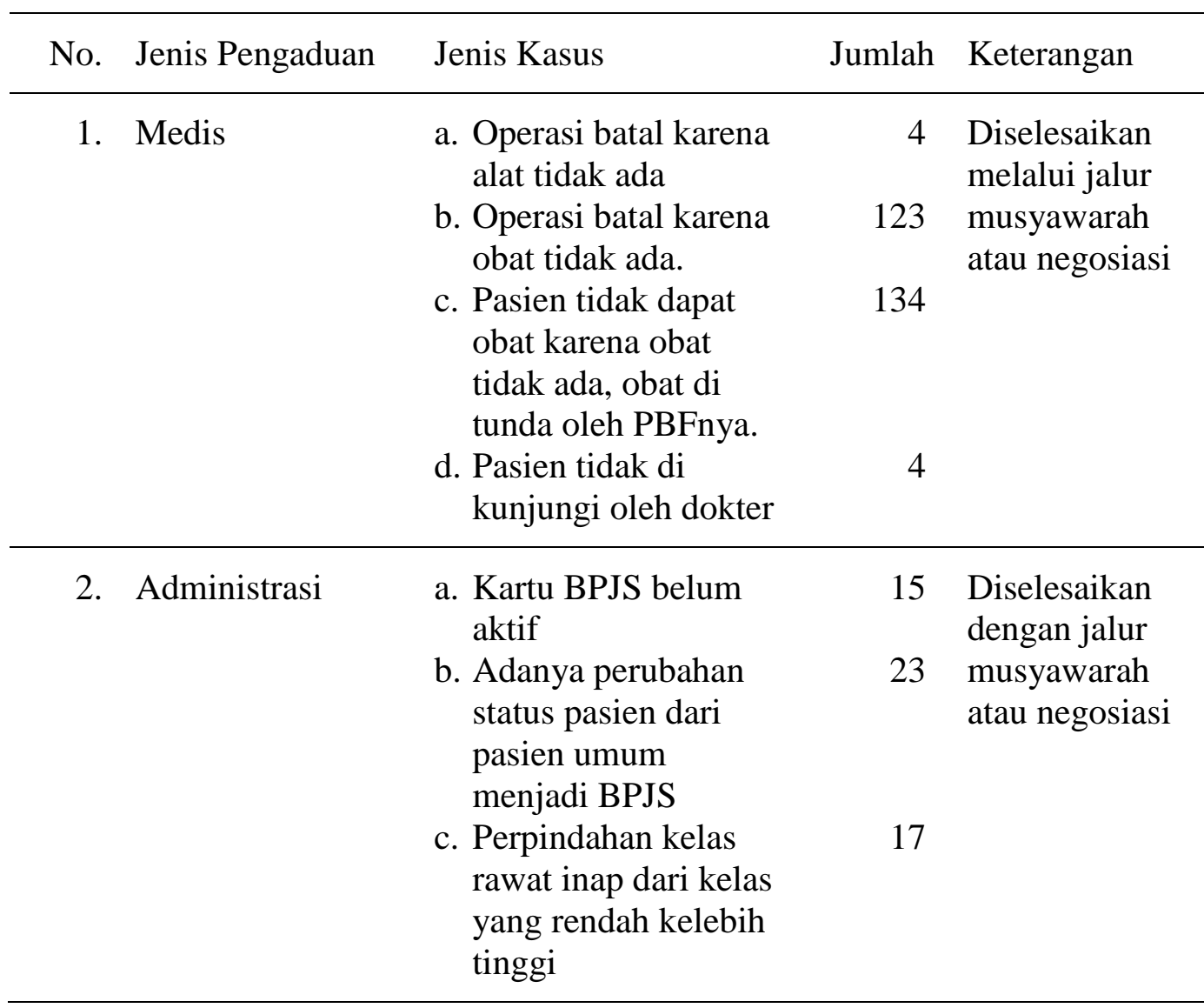

Sumber: Data lapangan diolah tahun 2016

Berdasarkan hasil wawancara dengan pihak RSUD Kota Pekanbaru, didapat keterangan bahwa pengaduan yang disampaikan pasien kartu BPJS kepada pihak rumah sakit sampai sekarang ini masih dapat terselesaikan dengan baik. Adapun sengketa antara pasien kartu BPJS dengan pihak RSUD Kota Pekanbaru diselesaikan dengan cara:

a. Upaya musyawarah atau mediasi

Kasus yang terjadi di RSUD Arifin Ahmad terhadap pengaduan yang disampaikan pasien pengguna kartu BPJS, diselesaikan dengan cara musyawarah, dan setiap pengaduan pasien ditelaah terlebih dahulu. BPJS Kesehatan Cabang Pekanbaru terus melakukan perbaikan terhadap pelayanan yang diterapkan bagi 15 rumah sakit yang ada di Pekanbaru. Upaya tersebut sebagai bentuk evaluasi 
yang kembali ditegaskan dalam perjanjian kerja sama antara BPJS Kesehatan dengan pihak rumah sakit. Jika RS melanggar kesepakatan dan muncul kasus pengaduan pasien maka dalam hal ini akan dimediasi oleh BPJS Kesehatan. Jika mediasi tidak bisa ditempuh maka BPJS Kesehatan akan memberikan surat peringatan pertama, surat peringatan kedua dan ketiga hingga diputusnya hubungan kerjasama.

b. Penyelesaian ke pengadilan

Penyelesaian melalui Pengadilan Negeri (PN) justru malah merepotkan kedua belah pihak yang berselisih. Selain waktu yang dibutuhkan sangat lama, mereka harus melewati proses persidangan yang cukup panjang yang diawali dari pengajuan gugatan, menghadirkan para saksi, sampai putusan dikeluarkan. Dalam kasus pengaduan pasien yang masuk tahun 2015, tidak adanya yang menempuh jalur penyelesaian dengan jalur Pengadilan. Semua pengaduan dapat terselesaikan dengan cara baik-baik atau musyawarah.

Pihak OMBUSMAN mengatakan bahwa selama berdiri dari tahun 2002 sampai dengan sekarang ini belum ada pengaduan tentang BPJS ini tetapi tentang kasus pelanggaran konsumen lainnya telah banyak diproses dengan bantuan OMBUSMAN seperti kasus dugaan mal praktek yang dilakukan oleh salah satu rumah sakit swasta di Kota Pekanbaru yaitu Rumah Sakit Ibu dan anak, pelanggaran haDXk konsumen pada pemberian kredit, dll. Pihak OMBUSMAN ini juga mengatakan bahwa kendala masyarakat tidak mengadukan atau menindak lanjuti permasalahannya karena ketidaktahuan masyarakat akan adanya OMBUSMAN ini dan mereka juga tidak mengetahui bahwa bantuan dari OMBUSMAN ini adalah secara cuma-cuma tanpa pungutan biaya dari pihak OMBUSMAN itu sendiri. Sehingga, masyarakat tidak perlu berpikir panjang jika dirinya ataupun keluarganya mengalami suatu permasalahan atau kerugian yang diakibatkan oleh produsen yang tidak bertanggungjawab (Haluan Riau. Hari Senin 2 Mei 2016: 19). 


\section{Simpulan dan Saran}

\section{Simpulan}

Berdasarkan uraian di atas, maka Perlindungan konsumen terhadap pasien pengguna kartu BPJS di RSUD kota Pekanbaru ditinjau dari UU No. 8 Tahun 1999, belum berjalan sebagaimana seharusnya, karena masih ada ditemui pasien pengguna kartu BPJS yang didiskriminasikan dalam pelayanan kesehatan yang diberikan oleh pihak RSUD jika dibandingkan dengan pasien umum lainnya. Penyelesaian sengketa akibat pasien pengguna kartu BPJS di RSUD kota Pekanbaru mendapatkan pelayanan tidak layak dapat ditempuh yaitu dengan musyawarah dan penyelesaian di Pengadilan.

\section{Saran}

Sehubungan masih adanya pelayanan tidak layak kepada pasien pengguna kartu BPJS di RSUD kota Pekanbaru, maka perlu ada pengawasan yang lebih ketat terhadap pihak rumah sakit dalam rangka memberikan perlindungan terhadap hak-hak pasien sesuai amanat peraturan perundang-undangan yang berlaku. 


\section{DAFTAR PUSTAKA}

\section{Buku:}

Departemen Kesehatan Republik Indonesia. 2006. Pedoman Penyelenggaraan Jaminan Pemeliharaan Kesehatan Masyarakat Miskin (ASKESKIN), Jakarta.

Mariam Darus Badrulzaman. 1986. Konsumen Dilihat Dari Sudut Perjanjian Baku (Standar) dalam Aspek-Aspek Hukum Masalah Perlindungan Konsumen, Bandung: Bina Cipta.

Ridwan, HR. 2006. Hukum Administrasi Negara, Jakarta: PT. Raja Grafindo Persada

Sidabalok, Janus. 2006. Hukum Perlindungan Konsumen di Indonesia, Pertanggungjawaban Menurut Hukum Perdata, Jakarta: Raja Grafindo Persada

Yusuf Shofie. 2003. Perlindungan Konsumen dan Instrumen-instrumen Hukumnya, Bandung: Citra Aditya Bakti

\section{Makalah dan Jurnal:}

Budiarso, A.W. "Undang-Undang Perlindungan Konsumen dan Dampaknya Kepada Pelayanan Rumah Sakit”. Makalah, Disampaikan pada Seminar Sehari IDI tentang Perlindungan Konsumen Pelayanan Kesehatan, yang dilaksanakan oleh Persi Pusat Jakarta tanggal 13 Nopember 1999.

Veronica Komalawati. "Aspek Hukum dalam Pelayanan Kesehatan: Suatu Kajian”. Jurnal Hukum Bisnis. Volume 23, No. 2, Tahun 2004.

\section{Peraturan Perundang-undangan:}

Republik Indonesia, Undang-Undang Dasar Tahun 1945

Republik Indonesia, Undang-undang Nomor 8 Tahun 1999, tentang Perlindungan Konsumen.

Republik Indonesia, Undang-undang Nomor 36 Tahun 2009, tentang Kesehatan

Republik Indonesia, Peraturan Pemerintah Nomor 32 Tahun, tentang Tenaga Kesehatan 
Republik Indonesia, Peraturan Pemerintah Nomor 6 Tahun 2000, tentang Perusahaan Jawatan (PERJAN)

\section{Internet:}

http://ariesaja.wordpress.com/about/hakdankewajibanpasien.sadarkahkita? diakses 19 April 2011.

www//http.bpjs.com., diakses 20 November 2015. 


\section{BIODATA PENULIS}

$\begin{array}{ll}\text { Nama } & \text { : Irfan Ridha } \\ \text { Pekerjaan } & : \text { Mahasiswa Program Pascasarjana Fakultas Hukum Universitas } \\ & \text { Riau } \\ \text { Jabatan } & :- \\ \text { Nomor HP } & :- \\ \text { E-mail } & : \text { irfanridha74@ gmail.com } \\ \text { Alamat Kantor } & : \text { Kampus Bina Widya Km 12.5, Simpang Baru Pekanbaru- } \\ & \end{array}$ 